\title{
Obesity is not always the answer
}

\author{
Partha Ray, ${ }^{1}$ Alexander Kenneth Mearns Pawsey, ${ }^{2}$ Jane Thomas Preston ${ }^{2}$
}

'Department of Surgery, James Paget University Hospital, Gorleston-on-Sea, UK ${ }^{2}$ Department of Obstetrics and Gynaecology, James Paget University Hospital NHS Foundation Trust, Great Yarmouth, UK

\section{Correspondence to}

Dr Partha Ray, partha.s.t.ray@googlemail.com Accepted 12 December 2015

\section{DESCRIPTION}

A 22-year-old woman (body mass index of $40 \mathrm{~kg} / \mathrm{m}^{2}$ ) repeatedly presented to her general practitioner (GP), with a diffusely tender and distended abdomen. She was told the reason for her symptoms was obesity. Eventually her GP referred her to A\&E department

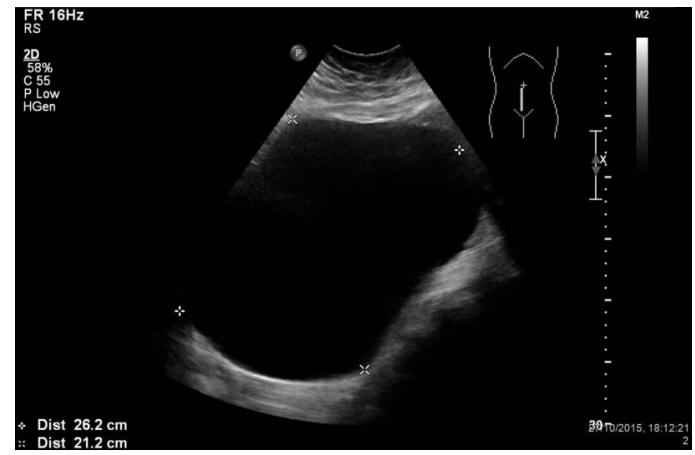

Figure 1 Ultrasound scan of the cyst measuring approximately $26 \mathrm{~cm} \times 26 \mathrm{~cm} \times 21 \mathrm{~cm}$. when she reported left-sided flank pain, to rule out renal calculi.

Ultrasonography revealed a large cyst extending from the symphysis to the xiphisternum, measuring approximately $26 \mathrm{~cm} \times 26 \mathrm{~cm} \times 21 \mathrm{~cm}$ (figure 1). Owing to previous pulmonary emboli in the patient's medical history, she was at high risk for malignancy, ${ }^{1}$ so a CT scan was performed, which confirmed a $27 \mathrm{~cm}$ (craniocaudal) $\times 27 \mathrm{~cm}$ (transverse) $\times 17 \mathrm{~cm} \quad$ (anterposterior) low-density (Hounsfield unit 9) cystic lesion (figures 2-4). The scan showed a single septa along the right lateral aspect of the cyst. There was a small area of soft tissue along the left lateral wall with a slightly thicker wall. There was no internal calcification or fat. The left adnexal origin of the cyst represented a large left-sided abdominopelvic ovarian cyst. A whirled appearance of the broad ligament/fallopian on the left suggested possible torsion. There was no free fluid, pelvic or para-aortic adenopathy. There was no evidence of peritoneal/omental or metastatic disease. All tumour markers were normal.

The patient eventually became septic. She was started on empirical antibiotics and expedited to
To cite: Ray $P$,

Pawsey AKM, Preston JT. BMJ Case Rep Published online: [please include Day Month Year] doi:10.1136/ bcr-2015-213784

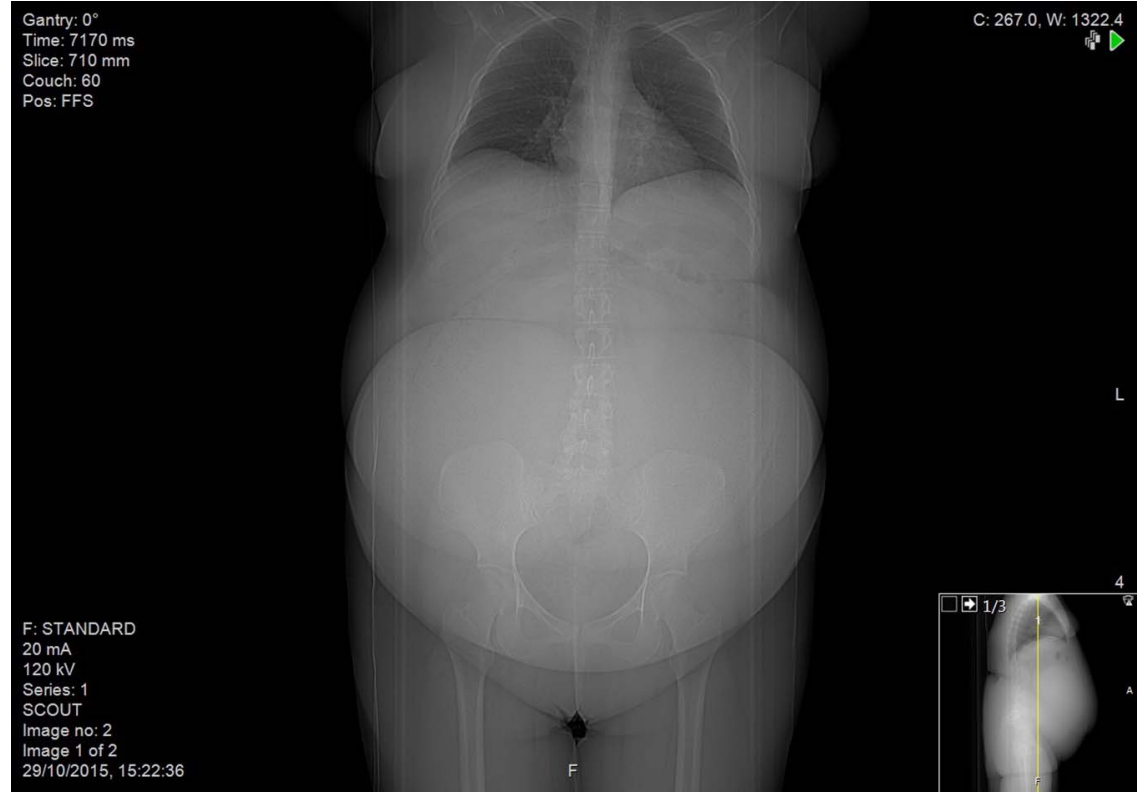

Figure 2 Coronal CT scan showing $27 \mathrm{~cm}$ (craniocaudal) ×27 cm (transverse) low-density cystic lesion. 


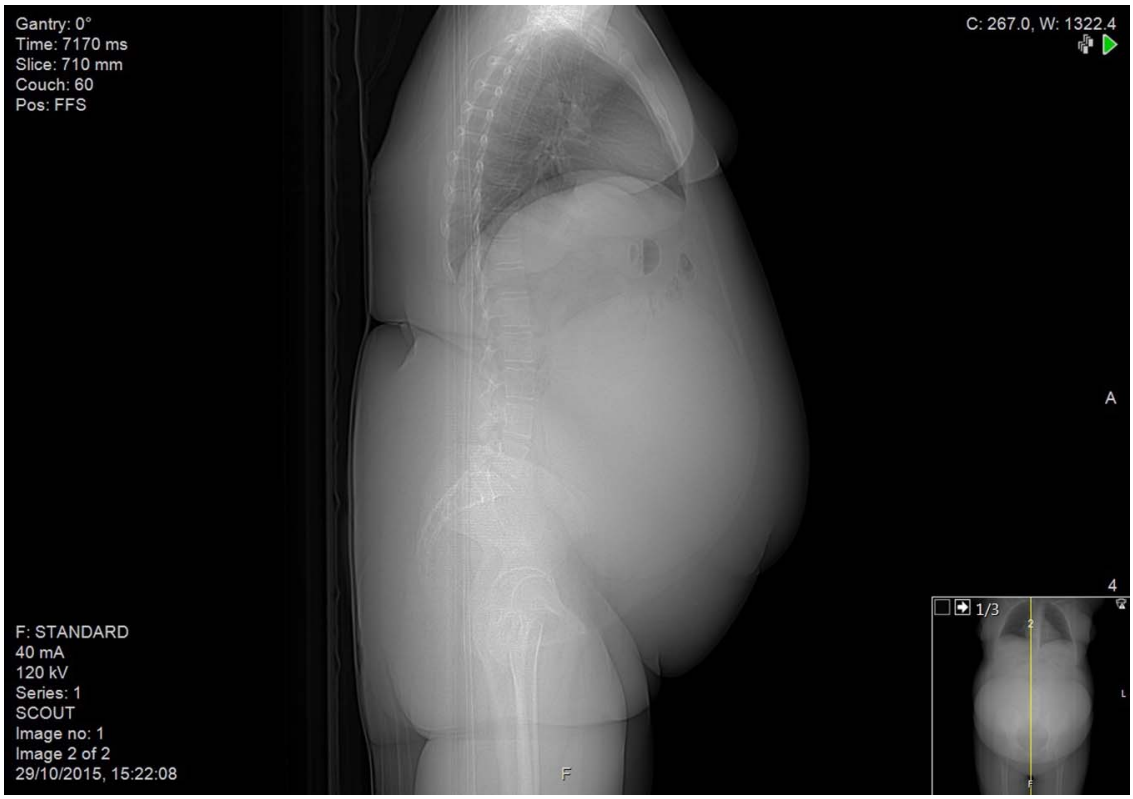

Figure 3 Sagittal CT scan showing $27 \mathrm{~cm}$ (craniocaudal) $\times 17 \mathrm{~cm}$ (anterposterior) low-density cystic lesion.

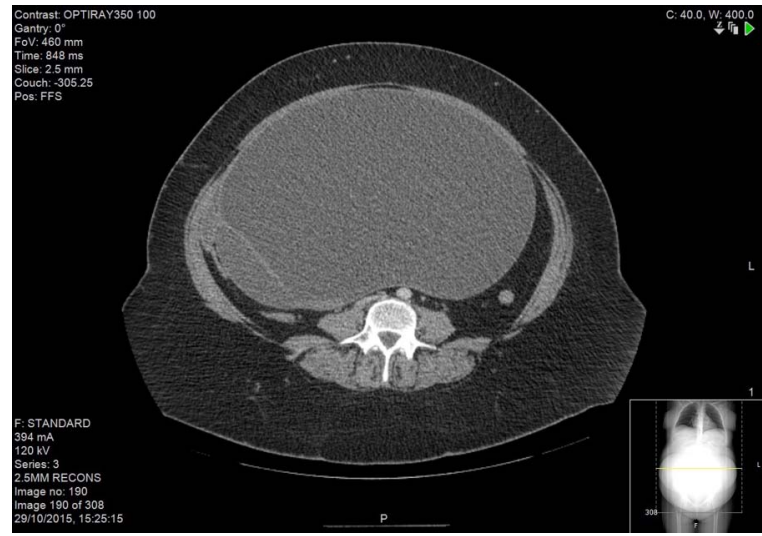

Figure 4 Transverse CT scan showing $27 \mathrm{~cm}$ (transverse) $\times 17 \mathrm{~cm}$ (anterposterior) low-density cystic lesion.

theatre for laparotomy, cyst removal and left oophorectomy. The cyst was multilocular and filled with $6 \mathrm{~L}$ of blood-stained fluid. There was no evidence of malignancy. The patient completed the course of intravenous and oral antibiotics.

Contributors JTP was responsible for the patient's care. PR and AKMP looked after the patient during her stay as an inpatient. All the authors contributed to the writing of the case report.

Competing interests None declared.

\section{Learning points}

- Patients with history of pulmonary embolism or deep venous thrombosis are at higher risk of malignancy. ${ }^{1}$

- Repeated general practitioner visits with recurring symptoms should warrant specialist opinion to rule out occult diagnoses. A simple ultrasound scan is a very useful tool when investigating acute abdominal pain and is a safe imaging modality in young female patients. ${ }^{2}$

- The management of obesity is complex because it has an underlying genetic basis that can be exacerbated by lifestyle and eating habits. ${ }^{3}$

\section{Patient consent Obtained.}

Provenance and peer review Not commissioned; externally peer reviewed.

\section{REFERENCES}

1 Sørensen HT, Mellemkjaer L, Steffensen FH, et al. The risk of a diagnosis of cancer after primary deep venous thrombosis or pulmonary embolism. N Engl J Med 1998;338:1169-73.

2 Mazzei MA, Guerrini S, Squitieri NC, et al. The role of US examination in the management of acute abdomen. Crit Ultrasound J 2013;5(Suppl 1):S6.

3 Kassir R, Blanc N, Tiffet O, et al. Obesity and the stool concept. Obes Surg 2015;25:129-30. 
Copyright 2016 BMJ Publishing Group. All rights reserved. For permission to reuse any of this content visit http://group.bmj.com/group/rights-licensing/permissions.

BMJ Case Report Fellows may re-use this article for personal use and teaching without any further permission.

Become a Fellow of BMJ Case Reports today and you can:

- Submit as many cases as you like

- Enjoy fast sympathetic peer review and rapid publication of accepted articles

- Access all the published articles

- Re-use any of the published material for personal use and teaching without further permission

For information on Institutional Fellowships contact consortiasales@bmjgroup.com

Visit casereports.bmj.com for more articles like this and to become a Fellow 